\title{
27
}

\section{Social Movements and Institutional Analysis}

\author{
Marc Schneiberg and Michael Lounsbury
}

Calls for reintroducing agency, politics and contestation into institutional analysis are now legion, spanning nearly two decades since DiMaggio's (1988) classic piece, and gaining new urgency as scholars struggle to explain institutional emergence and change. Institutionalists face persistent difficulties in these tasks. Working from arguments about isomorphism, diffusion, or path dependence, they often invoke ad hoc explanations like exogenous shocks in order to reconcile change and path creation with theories that stress the contextual sources of stability, continuity and conformity (Greenwood \& Hinings 1996; Clemens \& Cook 1999; Campbell 2004; Streeck \& Thelen 2005; Schneiberg 2005; Guillén 2006). To address these difficulties, institutionalists have begun to revise both their conceptions of fields and their views of action. From a structural standpoint, some scholars increasingly view fields as comprising multiple logics, or by indeterminacy, ambiguities or contradictions, opening theoretical spaces for action (Scott, Ruef, Mendel, \& Caronna 2000; Stryker 1994, 2000; Seo \& Creed 2002; Schneiberg 2002, 2007; Lounsbury 2007; Marquis \& Lounsbury 2007). Focusing more on agency, other scholars have brought new attention to actors and what they do, producing studies of 'institutional entrepreneurs' (Beckert 1999; Hwang \& Powell 2005; McGuire Hardy \& Lawrence 2004; Hardy \& McGuire, Chapter 7 this volume) and institutional work (Lawrence and Suddaby 2006). Within this milieu, scholars have also sought to overcome 'excessive institutional determinism' by turning to social movement theory and the study of collective mobilization.

Spanning sociology and political science, social movement theory has produced a wealth of concepts and research on change, including studies of students organizing to register black voters in the 1960s (McAdam 1988), the mobilization of farmers, workers and women to make claims on the state (Clemens 1997), shareholder activism to contest managerial control over corporations (Davis \& Thompson 1994), the growth of identity movements pursuing peace, gay/lesbian rights and environmentalism (e.g., Laraña, Johnston, \& Gusfield 1994), and the rise of transnational pressure groups (Keck \& Sikkink 1998). What these studies share is an interest in contestation and collective mobilization processes - how groups coalesce to make claims for or against certain practices 
or actors in order to create or resist new institutional arrangements or transform existing ones (McCarthy \& Zald 1977). They also share an interest in tracing how contestation and collective action rest on the capacity of groups to mobilize resources and recruit members, their ability to engage in cultural entrepreneurship or frame issues to increase acceptance of their claims, and the political opportunity structures that constrain or enable mobilization (McAdam, McCarthy, \& Zald 1996). This chapter focuses on how engaging collective mobilization and social movement theory has inspired new work in institutional analysis.

The integration of movements into institutional analysis has begun to revise existing imageries of institutional processes, actors, and the structure of fields, generating new leverage for explaining change and path creation. Regarding processes, it adds contestation, collective action, framing and selfconscious mobilization for alternatives to conceptual repertoires of legitimation, diffusion, isomorphism and self-reproducing taken-for-granted practices (Jepperson 1991; Colyvas \& Powell 2006). Regarding actors, it counter-poses challengers and champions of alternatives to standard accounts of states, professions and other incumbents as key players. Regarding structure, it moves away from images of an isomorphic institutional world of diffusion, path dependence and conformity toward conceptions of fields as sites of contestation, organized around multiple and competing logics and forms (Kraatz \& Block, Chapter 9 this volume).

As will be clear, work that integrates movements into neo-institutionalism parallels work on institutional entrepreneurship in key respects (Hardy \& McGuire, Chapter 7 this volume). Both emphasize agency, deliberate or strategic action, and self-conscious mobilization around alternatives. Both wrestle with problems or paradoxes of how actors embedded within institutions can change those systems, how institutions limit or support change, and how actors draw on the elements or contradictions of existing institutions to forge new ones. Both identify some of the same processes as critical for change, including framing, theorization, transposition, and the recombination of logics. Yet where institutional entrepreneurship research often attributes substantial casual efficacy to individuals, studies linking movements and institutionalism are more deeply rooted in structural perspectives. They thus place greater emphasis on politics and collective mobilization as motors of change, and more systematically address the relations between activity, collective organization and existing institutional contexts.

Our central claim is that analyzing movements within neo-institutional theory is essential for understanding when and how: (1) paths or fields become constituted around multiple, competing logics; and (2) multiple logics, contradictions and ambiguities fuel field-level change and new path creation. In making this claim, we accept, rather than dismiss, contextual arguments about durability, path dependence, and stability that give institutionalism its analytical edge in explaining continuity, differences or 'higher order' effects on organizations (Schneiberg \& Clemens 2006). Institutions often exhibit increasing returns and positive feedbacks (Pierson 2000). Actors empowered by existing institutions use their advantages to elaborate institutions in ways that preserve their power and preclude alternatives. Diffusion, adoption and the resulting communities of practice create isomorphic pressures that make conformity a condition for legitimacy, fueling further diffusion. Institutionalized theories of order render alternatives unthinkable, irrational or inefficient. And the prevalence of taken-for-granted understandings means that even opposition occurs in those terms, deepening the paths it contests.

In short, rather than simply assert an agentic, actor-centered institutionalism, we begin with the structural insight that limits on alternatives and pressures for continuity or convergence often exercise considerable force. Reflexive action, the capacity to articulate alternatives, the salience of multiple logics, or their translation into change, cannot 
be assumed. To the contrary, these are often fragile achievements which ultimately rest on the emergence and efficacy of social movements.

Using existing and ongoing research, this chapter outlines analytical strategies for addressing the rise and effects of movements on institutional fields. We pay particular attention to how those strategies revise existing institutional accounts of change and path creation. In parts I and II, we consider movements as agents and infrastructures of change, outlining two emerging approaches to what movements do and how they affect fields. One treats movements as forces against institutions; that is, as forces operating outside established channels to assert new visions and disrupt or directly contest existing arrangements, evoking legitimacy crises, sense-making and other institutional processes within fields. This approach revises two canons in institutional theory the two-stage model of institutionalization and histories of change as punctuated equilibrium. It also provides insights into how fields become constituted around multiple logics.

A second approach considers the rise and impact of movements within fields, examining movements as institutional forces or infrastructures for institutional processes including theorization, recombination and diffusion. This approach reveals how diffusion, translation and adoption are contested, political processes that often depend on collective action. It also sheds light on how movements emerge from and exploit contradictions or multiple logics within fields to mobilize support, forge new paths or produce change.

In part III, we turn from movements as agents of change to analyses of how contexts shape contestation and collective action. Institutionalists have recognized that existing institutions constrain and enable mobilization, create openings for challengers, and shape their capacities to produce change. This has led neo-institutionalists to the movements literature on political opportunity structure and institutional mediation (e.g., Amenta, Caruthers, \& Zylan 1992; McAdam 1999; Davis \& Thompson 1994), prompting new insights about opportunity structures, a reinvigoration of multi-level approaches, and new strategies for analyzing movements, existing institutions and change. Taking a decidedly cultural cast, these strategies reformulate arguments about political opportunity structures as institutional opportunity structures, highlighting how movements and change are endogenously shaped by institutions.

Based on these discussions, we turn in part IV to suggest new directions for research on how movements and institutional dynamics combine to produce change. One key direction is methodological: to develop clearer, more direct measures of movements and to exploit the analytical leverage of multivariate approaches. This will help assess and systematize claims from qualitative and historical work about movement effects and the relations between movements, institutional contexts and outcomes.

A second direction is to analyze movements as a political condition for diffusion and other institutional processes. Insofar as alternatives are contested or suppressed by vested interests, their diffusion will depend on collective action and the mobilization of power by champions of new practices and forms. In cases like these, movements can moderate institutional processes, supporting diffusion or translation in three ways: by serving as field-wide or cross-field mechanisms for mobilizing power, by working as political forces within organizations to increase their receptivity to alternatives, or by working between organizations to increase innovators' influence as exemplars. Taking this approach to how movements operate in fields can help explain the diffusion of alternatives and more diverse sets of outcomes related to practice variation.

Finally, we consider the origins of movements and institutions, taking an historical approach and considering the relationship between institutions and movements as an 
ongoing process in which combinations or sequences of movements cumulatively produce change. Movements might figure in the production of unintended and incremental trajectories of change. That is, even when they are defeated or their time has passed, movements may leave legacies, elements of institutional orders and bits and pieces of paths not taken, producing diffuse but important effects, and creating possibilities for subsequent movements, institution-building and transformation (Schneiberg 2007). Focusing on these possibilities sheds further light on how movements and their effects are endogenously produced, helping researchers avoid the trap of invoking movements, like exogenous shocks, as a deus ex machina.

\section{MOVEMENTS FROM OUTSIDE INSTITUTIONS: CHALLENGER/ DOMINANCE APPROACHES}

One way to integrate movements into institutional research preserves the analytical distinction between movements, contestation and deliberate mobilization, on the one hand, and institutional processes like the reproduction of taken-for-granted practices, on the other, taking movements as an 'extra-institutional' force that impacts change or new path creation. This approach hardly exhausts the possible relations between movements and institutions. But it captures the potentially wide class of cases where movements arise outside of or on the peripheries of established fields, acting as outsider-challengers to assert new visions of order, disrupt existing systems, or secure policies or representation from established authorities. Thinking in these terms also extends the institutional framework to highlight key processes left exogenous by existing accounts of emergence and change, opening up the black-box of 'pre-institutional' dynamics, and adding new imageries and mechanisms to our conceptual repertoire.

Consider two canonical formulations in neo-institutional analysis. In the two-stage model of institutionalization, the emergence of new paths or fields is a 'bottom up' phenomenon: (1) organizations or states adopt structures or policies in response to local problems, politics or characteristics, which then spark (2) processes of mimesis, theorization and diffusion, eventually crystallizing a broader community of practice around a core set of principles or models (Tolbert \& Zucker 1983; Baron, Dobbin, \& Jennings 1986; Galaskeiewz \& Wasserman 1989; Strang \& Chang 1993). As solutions diffuse, they become taken-for-granted as an accepted norm, serving as baselines to which organizations must subsequently conform as a condition for legitimacy. In punctuated equilibrium models, change occurs as a sequence of shock, disruption, deinstitutionalization, and reinstitutionalization (Edelman 1990, 2006; Fligstein 1990, 2001; Sutton et al. 1994; Sutton \& Dobbin 1996). Shocks like new laws or court rulings subvert existing routines, vested interests and established understandings, evoking uncertainty, sensemaking and a succession of players and models as new groups emerge to define the situation and establish their solutions as new bases of order.

Both models shed light on key institutional processes: (1) mutual monitoring, mimesis and the diffusion or transposition of practices across organizations; (2) theorization, codification or the endorsement of best practices by professional associations; and (3) interventions by states to ratify, redraw or reject field boundaries and emerging solutions (e.g., Strang \& Meyer 1993). Yet both tend to neglect the origins of new ideas and practices as well as the sources of disruption, leaving key players and processes unanalyzed. However, in many canonical cases featuring isomorphism, the instigating shocks or motivations for adoption were the direct and deliberate results of social movements municipal reformers and progressives fighting corruption in city government, civil rights activists demanding state intervention to end discrimination, and agrarian populists contesting corporate consolidation. 
Schneiberg and Soule's (2005) study of rate regulation in insurance develops one model of the role of movements in the institutionalization process, filling in gaps in the canonical accounts. It conceptualizes institutions as political settlements. And it analyzes path creation as a contested process grounded in sequences of mobilization, disruption and conventional institutional dynamics, tracing how mobilization outside established channels catalyzes path creation and change. Specifically, their study shows how rate regulation by American states in the early twentieth century was provoked neither by exogenous shocks, nor by scattered and unconnected politics or problem-solving behavior. Rather, it was sparked by anti-corporate movements including the Grange and Farmers Alliance who worked to contest corporate consolidation and assert alternative forms of economic order. This mobilization was a response to the rise of 'trusts' and 'combines' in various sectors. Grangers and other groups directly opposed 'corporate liberal' models of order based on for-profit corporations, national markets and unregulated industry. Instead, they pursued 'producer republican' logics that envisioned American capitalism as a regionally decentralized and cooperatively organized economy of independent producers, farmers and self-governing towns. Moreover, in targeting insurance, Grangers and other groups secured anti-compact laws to break up the 'insurance trust,' organized consumer-owned mutual firms, and otherwise disrupted insurance markets, fueling legitimacy crises, public hearings, and new interventions within key states.

These disruptions and interventions, in turn, sparked politics and conventional institutional processes within the insurance field. They evoked inter-state diffusion in which key players monitored other states, theorized rate regulation as a solution to the 'insurance problem,' recombined elements to forge those solutions and adopted laws passed by other states. They also evoked supra-state or field-wide process in which courts and the professions endorsed regulation, promulgated model laws, and built field-wide administrative organs. Taken together, these institutional processes shifted the balance of power within states, crystallizing insurance around economic models and regulatory solutions that settled political struggles over industry governance (see also Schneiberg 1999, 2002; Schneiberg \& Bartley 2001).

Rao, Clemens and Hoffman also go beyond canonical accounts by foregrounding movements, understanding paths as political settlements, or analyzing path creation as sequences of movements, mobilization and institutional processes. Rao (1998) shows how the consumer watchdog agencies and product rating schemes that are now takenfor-granted in the US were the product of consumer mobilization and contestation over whether scientific testing and the power of informed consumers should be blended with the role of labor, unionization and concerns about products. At first, consumer groups fought for two different logics of market reform, one that blended consumer advocacy with unionism and one that focused more narrowly on the consumer. But broader political dynamics eliminated the more comprehensive radical change frame from the path, segregating 'consumer' and 'worker,' and ensuring the dominance of a consumer-only impartial testing logic (see Carruthers \& Babb 1996 for a similar analysis of monetary systems).

Clemens (1993, 1997) more directly addresses how change flows from combinations of movements and institutional processes, tracing how interest group politics became a core feature of the American polity through successive waves of mobilization and transposition by three outsider/challenger groups. Acting collectively to contest parties and patronage, first unions, then farmers, and then women's groups built on previous efforts to disrupt existing arrangements (strikes, boycotts, protests) by transposing fraternals, cooperatives, clubs and other kinds of apolitical associations into mainstream politics. These sequences of 
actions fundamentally altered the terms of political representation and influence, creating access and clout for previously disenfranchised groups and institutionalizing lobbying, legislative monitoring, and other now taken-for-granted modes of American politics.

Hoffman's (1999) study of environmentalism likewise finds that movements and institutional dynamics play pivotal roles in field creation and change. Here, conflicts over competing institutions and successive rounds of environmental mobilization, scandal and legislative activity provoked new forms of discourse, theorization, and new patterns of interactions among firms, non-profits and governments. These dynamics, in turn, helped produce an increasingly structured environmental field.

As a group, these studies substantially revise canonical accounts of path creation and change. First, they support a view of institutions as settlements of political struggles over the character of fields fueled by the mobilization of challengers around competing projects and logics (Davis \& Thompson 1994; Fligstein 1996; 2001; McAdam \& Scott 2005; Armstrong 2005). Emphasizing contestation and collective action, this view departs from 'cooler' imageries of paths as based mainly in diffusion, taken-for-granted practices, theorization and normative endorsement by professions or states. Thus, insurance rate regulation represented a political solution of struggles between insurers, who pursued economic logics of corporations, markets and unregulated industry associations, and challenger groups, who sought anti-trust laws, regulation and mutual alternatives to promote more regionally decentralized and cooperatively organized economies. Conflicts over these visions yielded structural innovations, but were not resolved until field members crafted packages that combined regulation with private association, and mutuals with for-profit corporations. The consumer advocacy field likewise reflected a settlement of struggles and mobilization around competing logics, albeit one which involved a clear cut victory of one logic of consumerism over other.

Second, these studies suggest an image of the process of institutionalization as a sequence or interaction between contestation and mobilization around alternative visions of order, on the one hand, and more conventional institutional dynamics, on the other. In insurance, challengers mobilized outside the system to contest the 'insurance combine' and forcibly impose alternative forms and anti-trust policies on the industry. Regulators and reformers within the field responded, in turn, by theorizing, endorsing and diffusing regulatory policies which recombined multiple forms into new packages. Multiple dynamics likewise figured in the case of American state building, where farmers, unions and women's groups progressively institutionalized modern interest group politics in the US via successive waves of mobilization, contestation and translation

Third, these studies provide a more varied understanding of how movements fuel path creation and change by mobilizing outside established channels to contest extant systems. At a minimum, by introducing multiple logics and promoting awareness of problems, challenger movements subvert the takenfor-grantedness of existing arrangements, fueling legitimacy crises and institutional politics (Stryker 2000), and providing insiders with cultural resources for criticism, reflexive action or 'mindful deviation' (Garud \& Karnoe 2001). Thus, as anticorporate forces, consumers and women's groups took action and asserted new logics, they not only evoked media attention and public debate, creating openings for challengers and reformers to delegitimate dominant institutional systems. They also supplied experts, reformers and other groups with models and cultural resources for criticizing and revising extant paths such as by combining or layering them with new forms and elements.

Moreover, challenger movements are often carriers of new organizational forms, and can work around or outside established channels to build parallel, alternative systems of organizations (Rao, Morrill \& Zald 2000; Carroll 
\& Swaminathan 2000; Schneiberg 2002; Schneiberg, King \& Smith 2008). These efforts may not be disruptive in intent. Yet promoting alternative forms can foster new competitive dynamics and populate fields with instances of new logics. By translating apolitical forms of association into state, agrarians, unions and women's groups altered both the terms of competition in American politics and prevailing conceptions of appropriate political action. By promulgating mutual insurance, Grangers and other groups both instantiated cooperativism and transformed the terms of economic competition in a key sector, forcing insurance corporations to engage in new forms of rivalry based on prevention, re-reengineering and loss reduction. And by introducing the science-based, not-for-profit product testing agency, the consumer movement transformed the terms of trade throughout the economy.

Furthermore, challenger movements can mobilize masses, networks and political support to pressure states and other power centers for new agencies, laws and policies that ban or mandate practices. As scholars have shown, the uncertainties or prohibitions associated with new laws, agencies, and mandates can profoundly destabilize existing systems, fueling sustained institutional dynamics (Fligstein 1990; Edelman 1992; Dobbin \& Dowd 1997; Hoffman 1999). Finally, outsider groups like ACT UP and Earth First! can and do use protests, boycotts and direct actions to dramatize problems and directly disrupt daily operations and routines (Elsbach \& Sutton 1992; Hoffman 1999). In all of these ways, movements can fuel path creation and change as political-cultural forces for contestation, confrontation and disruption. Instantiating new logics, they can evoke controversy and debate within fields, conflicts and policy responses within organizations, inter-organizational diffusion and field-wide association, while supplying insiders and reformer with templates, political support and cultural resources for theorization, transposition, recombination and the assembly of new institutions.
Simple in its essentials, a conception that emphasizes sequences of outsider movements, mobilization and institutional processes has supported increasingly sophisticated analyses of path creation and change. As we show in part III, a 'movements from outside institutions' conception lends itself readily to multilevel analyses of fields, and to consideration of how existing institutions or political opportunity structures shape challengers' capacities to mobilize and effect change. Yet this conception does not exhaust the ways that movements figure as agents of path creation and change.

\section{MOVEMENTS WITHIN INSTITUTIONS: COLLECTIVE MOBILIZATION AS INSTITUTIONAL PROCESS}

Groups seeking change often mobilize collectively outside established institutions to assert new logics and disrupt taken-forgranted arrangements. Yet institutionalists have recognized movements also arise within institutions or fields, mobilizing insiders and well as outsiders, using established networks and resources to diffuse alternative practices, and drawing effectively on existing institutional elements and models to craft new systems (see Fligstein 1996, 2001). Indeed, while movements can drive change by directly opposing existing schemes, generating legitimacy crises or otherwise disrupting institutions, they sometimes promote path creation and change incrementally by engaging in institutional processes (or becoming institutional forces). That is, movements can emerge and operate within established channels and power structures, drawing on existing institutions and taken-for-granted understandings to theorize, articulate and combine new projects or practices with prevailing models and arrangements. In so doing, movements may themselves become vehicles or established channels for diffusion, theorization, recombination and other institutional processes within fields. 
This broader conception of movements risks a loss of analytical specificity and a diminished focus on contesting power structures, especially where movements become synonymous with collective or quasi-collective action geared toward any type of change (Scully \& Segal 2002; Scully \& Creed 2005). Yet analyzing movements as intra-institutional forces productively blurs distinctions between 'extra-institutional' and 'institutional,' 'mobilization' and 'self-reproducing' process, or 'contentious' versus 'conventional' politics. It has led to new insights about parallels between institutional phenomena and collective action processes studied by movement scholars (Campbell 2005; Strang \& Jung 2005; Davis \& Zald 2005; Wade, Swaminathan, \& Saxon 1998). It has led to new understandings of the relations between movements and institutions, including how institutional reproduction and diffusion depend on mobilization, political resources and contestation (Thelen 2004; Hargrave \& Van de Ven 2006). It supports research that goes beyond analyzing movements as 'extra-institutional' producers of multiple logics to consider also how movements and contestation are products of - and mobilize - contradictions and multiple models within fields (Strkyer 2000; Seo \& Creed 2002; Morrill 2006). And it has let institutionalists interested in movements supplement images of change as disruption, conflict and settlement with analyses of how movements also work in an incremental and embedded fashion, producing trajectories of path creation or change as reconfiguration, recombination or layering (Clemens \& Cook 1999; Streeck \& Thelen 2005; Schneiberg 2007).

Lounsbury and colleagues' studies of recycling address how movements can enter into and operate within fields as institutional forces, emphasizing their role as agents of theorization, classification, and the diffusion of codified arguments, frames or theoretical resources (Lounsbury 2001, 2005: Lounsbury, Ventresca, \& Hirsch 2003). Initially, eco-activists pursued recycling outside established channels, working independently of and against the waste industry to organize thousands of local non-profit, drop-off recycling centers. Such efforts were part of a broader project to restructure capitalism. They were articulated within a holistic frame that theorized recycling as a way to rebuild community, create local closed-loop production and consumption, and reduce community dependence on conglomerates and capitalist commodity systems. Yet the commitment of industry and state agencies to a resource recovery logic which emphasized landfill, waste-to-energy programs and large-scale incineration left the recycling movement isolated and its centers without outlets for materials.

In fact, a viable infrastructure for recycling did not emerge until activists, working through the National Recycling Coalition, entered mainstream policy negotiations, forged ties with solid waste handlers, and retheorized recycling as a for-profit service that built on curbside programs and complemented landfills and incineration. Coupled with grass-roots mobilization against new incinerators, and negotiations with state agencies to buy recycled materials, theorizing recyclables as commodities transformed cultural beliefs and discourse about waste in the industry, creating institutional conditions for diffusing recycling practices (see also Strang \& Meyer 1993; Strang \& Soule 1998; King, Cornwall, \& Dahlin 2005).

In addition, environmental movements also served as institutional forces by operating inside organizations (see Zald \& Berger 1978 for an early statement on movements within organizations). The Student Environmental Action Coalition promoted recycling within universities by codifying arguments, building inter-collegiate networks and disseminating standardized arguments and facts about similar programs elsewhere. And the College and University Recycling Coordinators provided universities and colleges with standards and classification schemes for measuring the progress, costs and benefits of programs, which helped 
deepen discourse and theorization of recycling as a rational economic activity. Thus, as Greenwood, Suddaby and Hinings (2002) document for professional associations, social movements can create cultural and theoretical foundations for new activities, forms and fields (see also Moore 1996, and Frickel \& Gross 2005 for examples of movements among scientific professionals). They can operate within existing power structures as agents of theorization, classification and diffusion, and can themselves become infrastructures for those processes within fields. Indeed, as recycling became institutionalized, the movement itself blurred into professional associationalism. Activists became recycling employees; employees used the National Recycling Coalition to form a professional association; and the association forged new identities, statuses and procedures for recycling managers within the new field.

Research by Morrill, Creed, Scully and colleagues, and Moore on the institutionalization of alternative dispute resolution, domestic partner benefits, and public science likewise document how movements operate as forces within mainstream institutions, de-emphasizing confrontational tactics in favor of their role as mobilizers of multiple logics and as agents or vehicles for recombination, assembly, translation and diffusion. In Morrill's (2006) study of alternative dispute resolution (ADR), mobilization for alternatives and contestation themselves rested fundamentally on the presence and recombination of multiple logics of practice in the socio-legal field. In this case, institutional processes of bricolage, hybridization and innovation preceded broader mobilization. Lawyers, social workers, community activists and judges working at the interstices or overlaps between fields during the 1960s drew in an ad hoc fashion on therapeutic techniques, community mediation, and other forms of non-adversarial negotiating and group discussion to help process minor disputes in small claims, family and other courts. As the 'litigation crisis' deepened, these early efforts supported the mobilization of two competing critical masses of ADR activists - one around a 'community mediation' model, the other around the 'multi-door courthouse.'

Both groups devoted considerable energy into theorizing and disseminating their approach, holding conferences, publishing manifestos in prominent law journals and seeking support from foundation or other established centers. Both also worked hard to articulate and recombine their models with prevailing models and institutions, including the 'Great Society' vision of federally funded community social programs and the increasingly ascendant new federalism. Moreover, once advocates could articulate ADR with the divorce revolution and no-fault divorce as a non-adversarial solution to custody and interpersonal problems, they gained a lever for professionalizing mediation and diffusing its practices. They used conferences, new organizations, instructional videos, newsletters, and the like to further codify and disseminate ADR, effectively layering ADR into the legal system as an increasingly taken-for-granted complement to conventional legal arrangements.

Creed, Scully and colleagues' studies of gay rights/GLBT activists shed additional light on how movements working within existing institutions can help establish new practices by exploiting contradiction and multiple logics, importing or redeploying logics across settings, and articulating or recombining new elements with prevailing models, myths or concerns (Creed \& Scully 2000; Creed, Scully, \& Austin 2002; Scully \& Segal 2002; Scully \& Creed 2005; see also Raeburn 2004). Decisive here were activists' use of contradiction and recombination to disturb taken-for-granted assumptions, highlight injustice, and legitimate claims for reform. For example, activists strategically deployed identity in face-to-face encounters with co-workers and supervisors. They used casual mentions of partners' gendered names when sharing experiences of mundane activities and enacted non-stereotypical behavior 
to challenge stigma. They also employed narratives of discrimination or inequality to highlight hypocrisies, evoking understandings that everyday routines produce injustice, and activating listeners' identities as nonprejudiced persons.

In addition, activists used their knowledge and status as insiders and loyal corporate citizens to couch reforms like domestic partner benefits as good business practice or expressions of firms' espoused commitments to diversity. Furthermore, like those fighting for the federal Employment Non-Discrimination Act, activists within firms imported higher order logics or frames, articulating domestic partner benefits and other gay-friendly policies with broader civil rights frames, values of fairness and equality, corporate social responsibility, and concerns with competitiveness in an increasingly diverse world. In a sense, GLBT movements worked for change by simultaneously coming out and fitting in; that is, by carefully articulating and combining difference, assertions of GLBT identity and new practices with 'normal' everyday life, insider identities as dutiful corporate citizens, and ongoing organizational concerns. Here too, diffusion of new practices like domestic partner benefits was a political process, resting on mobilization, contestation, framing and the recombination of prevailing models and cultural elements in and across firms.

As Moore shows, the institutionalization of public science organizations in American politics also rested critically on multiple logics, mobilization by insiders, and the role of movements as bricoleur-agents of recombination and redeployment (Moore 1996; Moore \& Hala 2002). During the 1960s and 1970s, university scientists faced increasingly severe contradictions between the logic of public service or social utility, on the one hand, and the logics of objectivity, non-partisanship and detachment as scientists, on the other. In fact, extant ways of joining science and politics - serving the public interest by serving the state - had become distinct liabilities. University scientists not only faced attacks by anti-war and environmental groups for their connections to the military and chemical industry, but they also began to criticize themselves and their peers for these connections.

At first, activists tried to link science and politics and mobilize for change within established science associations. But mixing partisanship and 'pure science' produced public discord within the scientific community and directly challenged its legitimacy as an impartial, objective producer of facts. This led scientist-activists to create a hybrid form - the public science organization - that resolved this tension by recombining science and politics in novel ways. Through dedicated organizations like the Union for Concerned Scientists and Scientists' Institute for Public Information, scientists could provide nuclear safety information, challenge non-scientists' uses of science, and address the public interest without risking their credibility as scientists by acting in openly partisan ways. Moreover, hybrid organizations separate from professional and political associations provided activists with a vehicle for public science that directed attention away from the inner workings of the scientific community, letting scientists mobilize politically without calling their legitimacy as scientists into question or sparking conflict within professional communities.

All of these studies highlight rich opportunities for exploring the role of movements within existing institutions and organizations. In general, social life is rife with collective mobilization, and whether these efforts are made by challengers working as outsiders to redefine existing arrangements, insiders seeking change from within, or elites striving to keep existing structures intact (Fligstein 1990, 1996), a focus on movements expands our understanding of institutional dynamics. Moreover, mobilization can occur at the level of the field as with anti-corporate forces or ecological activists promoting communitarian alternatives to corporate capitalism and with scientists forging new associations to link expertise to politics. 
Or it can occur within and between organizations as recycling advocates pressed for more substantive forms of recycling or as gay and lesbian groups pushed for recognition and benefits. A focus on movements, therefore, sheds new light on path creation and change, particularly when it attends to the multi-level character of the institutional context.

To be sure, the distinction between movements operating outside and inside fields raises questions for future work about their different enabling conditions, trajectories or effects. Insiders will more likely pursue different tactics and forms of contestation than outsider groups. They will likely obilize collectively in different ways, frame problems and solutions differently, and differentially negotiate or exploit structures, networks and institutional frames provided by established fields. And they may be more likely to err on the conservative side. Conversely, outsiders pursuing disruptive activities face legitimacy dilemmas that may pressure them to mobilize as insiders, articulate their projects with existing institutional logics, or form separate, decoupled organizations for disruptive and conventional action (Elsbach \& Sutton 1992; Lipsky 1968). And, as we suggest in part IV, we can also profitably consider how outsider and insider movements occur in waves or sequences, producing historical trajectories of change. Fortunately, future work on both kinds of movements can exploit existing research on how institutional contexts more generally shape mobilization and movement efficacy.

\section{INSTITUTIONAL FIELDS AS CONTEXTS FOR MOVEMENTS}

While the work just described provides rich depictions of movements as agents of institutional creation and change, analysts of 'outsider' and 'insider' movements have also paid careful attention to the institutional context of social movements. They have not only begun to theorize how multiple logics within fields can motivate contestation and collective action (Stryker 2000; Seo \& Creed 2002; Morrill 2006), they have also considered how existing institutional contexts shape mobilization and movements' capacities for producing change. Indeed, addressing relations between movements, institutional contexts and outcomes lays the foundation for more sophisticated analyses of power and agency. It lets scholars go beyond simple power elite or interest group arguments about agency and change to consider how extant institutions block access, provide challengers with lever and openings, and otherwise condition actors' ability to translate numbers, resources or organization into change. Moreover, in exploring relations between movements, contexts and outcomes, institutionalists have made good use of research on political opportunity structure (McAdam 1999; Tarrow 1998; McAdam, Tarrow, \& Tilly 2002) and related arguments about institutional mediation (Amenta, Carruthers, \& Zylan 1992; Amenta \& Zylan 1991) and institutional contingency (Thornton \& Occasio 1999; Bartley \& Schneiberg 2002; Schneiberg Clemens 2006; Lounsbury 2007), supporting a deepening integration of movements research and neo-institutional analysts.

Work at this interface has identified various features institutional and political fields that condition movement dynamics or success. These include the legacies of prior policies, the receptivity of institutional authorities toward challengers' claims, the concentration of resources within a field, and the prevalence of certain cultural models. Work on contexts has also shown how the multi-level character of fields provides openings for challengers, and how movements evoke counter-movements within fields.

Davis and colleagues' studies of shareholder movements nicely document how success may hinge on the institutional context (Davis \& Thompson 1994; Davis \& Greve 1997; Davis \& McAdam 2000; Vogus \& Davis 2005). During the 1980s, shareholder activists mobilized to promote new conceptions of the 
corporation, transform the markets for corporate control, and break the hold of vested managerial interests over large US firms. To this end, shareholder groups formed new organizations, launched takeover actions against individual firms, used existing governance machinery to oust entrenched managers, and sought legislative and regulatory changes, relying on their considerable material resources and connections. Yet activists' ability to translate resources into change was institutionally and organizationally mediated. The concentration of assets held by institutional investors provided shareholder activists with critical leverage in firm-level conflicts with management over the control of corporations. The SEC's review of proxy, rules weakened managers' ability to control votes and signaled a favorable regulatory stance toward shareholders and corporate reform. State governments that were heavily dependent on franchise fees for incorporation were reluctant to alienate shareholder groups by passing anti-takeover statutes that would deprive shareholders of a key weapon. And prosperity made it harder for vested interests to use fears of economic ruin to mobilize political support for anti-takeover legislation.

Soule and her colleagues likewise trace how the ability of the women's movement to secure equal rights amendments from American states rested on political and institutional opportunity structures (Soule \& Olzak 2004; Soule \& King 2006). Mobilization for equal rights amendments was more likely to result in ratification in states with a high level of electoral competitiveness, extensive histories of prior civil rights legislation, and favorable (Democratic) allies in power. It was also more effective in public opinion climates characterized by the prevalence of new conceptions of women's roles in private and public spheres.

Findings that public opinion climates enhance prospects for movements are particularly noteworthy here, as they move beyond traditional realist formulations about political opportunity structure to consider how culture shapes mobilization and change. Some of the studies discussed above highlight how institutionalized models or logics represent cultural resources for mobilization, framing and change. So does research by Lounsbury and Hironaka, Schofer and Frank. Shifts in the recycling field from a radical, holistic logic to a technocratic logic facilitated the creation of recycling advocacy groups in urban regions in response to contest waste management through incineration (Lounsbury 2005). More broadly, the diffusion of environmentalism as a global blueprint for the nation state has enhanced the capacity of domestic environmental activists to organize and slow environmental degradation (Frank, Hironaka, \& Schofer 2000; Hironaka \& Schofer 2002; Schofer \& Hironaka 2005). As these studies suggest, formal mechanisms (e.g., environmental impact assessments) and the prevalence of global environmentalism as a valued cultural model have legitimated environmental movements, fueling organization, while creating rhetorical and procedural opportunities for activists to point out failures and pursue legal actions.

Research on movements and institutional contexts has also documented how the multi-level or federated character of institutions sometimes creates opportunities for movements. The multi-level nature of fields is central to institutionalist imageries of context (Scott 2001; Schneiberg \& Clemens 2006), and bears directly on movements' capacities to produce change. As Davis and colleagues' analyses of shareholder activism show, challengers sometimes have to mobilize simultaneously at multiple levels within fields to assert new models and effect change (Davis \& Thompson 1994; Davis et al. 1994; Davis \& Greve 1997; Vogus \& Davis 2005). Shareholder group were mainly interested in promoting new conceptions of the corporation and contesting entrenched management at the firm ('lower order') level. But they quickly found that they had to take the fight to the state and federal level. Influencing these 
'higher order' units were essential for challengers' ability to make change, since state and federal laws set the terms for mobilization and access at the firm-level, defining rules for proxy systems, takeovers and whether shareholders could act collectively. By blocking anti-takeover legislation, securing new proxy rules, and so on, shareholder activism at state and federal levels created critical opportunities for mobilization against and within corporations.

The fractured and multi-level structure of institutions also enabled anti-corporate groups to get insurance rate regulation on the states' agenda in the early twentieth century (Schneiberg \& Soule 2005; Schneiberg \& Bartley 2001; Schneiberg 1999). Challengers seeking decentralized, producer republican models of economic development were largely closed out of policy making and had little leverage for their regulatory ambitions in New York, Connecticut and other centers of the 'insurance combine.' But the more peripheral, agrarian states proved more open to populist pressures, enabling agrarian and independent producers to assert statist regulatory measures in the insurance field, disrupt markets, and organize mutuals. Insurers tried to close off access entirely by suing in state and federal courts to void states' rights to regulate insurance prices. Yet, that strategy backfired when advocates of regulation found an unexpected ally in the US Supreme Court, which opened the door for further intervention in states by ruling that insurance was 'affected with a public interest' and thus subject to the states' authority.

Indeed, the multi-level character of fields creates possibilities for movements to couple field-level and intra-organizational mobilization, with the characteristics of organizations serving as opportunity structures that shape the capacities of movements within organizations to produce change. For example, universities and colleges that had previously experienced recycling activism on campus hired full-time ecologically-committed coordinators and created full-blown recycling programs while schools without movements tended to adopt a more minimalist approach that was staffed by part-time custodial staff (Lounsbury 2001). Moreover, ecological activists were better able to gain footholds for securing programs at larger college and universities with more resources, selective colleges with histories of activism, and universities with environmental majors that could serve as local allies or institutional conduits for field-level pressures.

Finally, researchers attending to context have also found that outcomes are shaped by whether or not initial movements catalyze counter-movements within fields. Vogus and Davis' (2005) study of anti-takeover legislation takes one step in this direction by analyzing how managerial and local elites counter-organized in response to shareholder activism to obtain legislation that protected corporate managers from raiders and hostile takeovers. Soule and colleagues' analyses go one step further. In analyzing states' adoption of the Equal Rights Amendment, they simultaneously include variables for the presence or strength of women's movement groups (NOW and AAUW) and anti-ERA organizations (Soule \& Olzak 2004; Soule \& King 2005). Similarly, in modeling the passage of anti-hate crime laws, they include counts of pro-gay community organizations and community centers, on the one hand, and measures of conservative group lobbying and the presence of a Family Policy Council, on the other (Soule 2004). Ingram and Rao (2004) also think in terms of movements and counter-movements, but elaborate a different research strategy, analyzing the passage and then the repeal of legislation banning chain stores as indicies of populist mobilization and chain store countermobilization over the rise of new market forms. In this way also, the capacities of movements to promote change or new path creation rests not just on size, resources or movement strength, but also on the structure and dynamics of the political and institutional context. 


\section{SOCIAL MOVEMENTS AND NEO-INSTITUTIONAL THEORY: FUTURE DIRECTIONS}

We conclude our review by discussing new frontiers for analyzing combinations of institutional process and social movements as sources of path creation and change. Future work, we suggest, can and should attend more carefully to key methodological issues of measurement and modeling. It can also fruitfully consider how movements produce change as political forces or conditions for diffusion, while simultaneously addressing how movements are endogenously produced and always institutionally conditioned. Such an approach captures the substantial benefits of introducing contestation and collective action into institutional analysis. But it does so while avoiding the traps of either invoking movements as extra-institutional forces or simply using movements to assert agency and abandon institutional context entirely. Such an approach, in other words, engages, rather than avoids, the paradoxes of embeddedness and analytical impasses involved in explaining path creation and change (Seo \& Creed 2002; Schneiberg 2007). We begin with a discussion of methodological issues, and then emphasize two major substantive categories for future research - the outcomes of movements and the origins of institutions and movements.

\section{Measuring and modeling movements}

Much of the work on movements from a neoinstitutional perspective has relied on qualitative and historical methods, playing to those methods' strengths in theory construction and producing a rich body of theory and thick descriptions. Supplementing qualitative work with multivariate quantitative research can not only help systematize theory construction in important ways, it can also help clarify causal relations, isolate effects, and strengthen inferences about movement emergence and outcomes.
There are substantial methodological challenges involved in documenting movement effects on path creation and institutional change, challenges that literally multiply as researchers address the moderating influence of existing institutional contexts. At a minimum, documenting movement effects depends on credibly measuring the development, strength and activities of challenger movements. Existing research linking movements, organizations and institutions has made real progress here, using the presence of movement organization or chapters, counts of movement organizations, and the number of movement members to document movement emergence and strength (e.g., Lounsbury 2001; Schneiberg 2002; Soule \& King 2006). It also suggests that future work can more directly tap such effects by measuring protests and other movement activity, or by using newspaper coverage, public hearings or other measures of controversy to assess whether movements have been able to force issues or new conceptions on the public agenda or call existing arrangements into question.

Documenting movement effects also rests critically on using movement research and multivariate approaches to isolate and disentangle the effects of movement strength or activity, mobilizing structures, framing, and institutional or political opportunity structures (for exemplars, see Vogus \& Davis 2005 and Soule \& King 2006). Absent multivariate designs or careful comparative analysis, inferences about movement effects on change remain vulnerable to counterclaims about spurious relations.

Furthermore, designing research that attends explicitly to multiple factors is particularly important for addressing how existing institutions and opportunity structures enhance or undermine movements' capacities for influence, disruption, and new path creation. Research on institutions or political opportunity structures sometimes analyzes those factors additively. But whether made by movement scholars or neo-institutionalists, arguments about political opportunity 
and institutional mediation are fundamentally arguments about interaction effects (Thornton \& Occasio 1999; Bartley \& Schneiberg 2002; Schneiberg \& Clemens 2006). They are arguments that political or institutional configurations amplify or blunt the effects of movement numbers, resources or activities on policies, paths and change. And they can be implemented empirically in relatively straightforward ways (Amenta \& Zylan 1991; Amenta et al. 1992; Schneiberg 2002; Soule \& Olzak 2004; Soule 2004).

\section{Mobilization outcomes: movements, politics and (heterogeneous) diffusion}

A second, more substantive direction for future research revisits the relationship between collective mobilization and diffusion, and considers how movements operate as political forces in promoting the spread of alternatives. Thinking in these terms keeps politics and power at the forefront of a reconstituted institutional analysis, while highlighting how diffusion is often a contested political process (Schneiberg \& Soule 2005; Fiss \& Zajac 2005; Hirsch \& Lounsbury 1997). Researchers have demonstrated that social movements can shape the composition of fields and fuel path creation by promoting new kinds of forms such as craft breweries (Carroll \& Swaminathan 2000), nouvelle cuisine (Rao, Monin, \& Durand 2003), mutual, cooperative and state enterprises (Schneiberg 2002, 2007), and communitybased, non-profit recycling centers (Lounsbury, Ventresca, \& Hirsch 2003; see also Clemens 1997; Rao, Morrill, \& Zald 2000). Yet as also noted, mobilization can spark counter-mobilization by powerful vested interests threatened by novel practices, pitting industrial brewers against craft producers, managers and unions against shareholders, or corporations against cooperatives and state enterprises. Such counterattacks are typically political, often involve state power, and can hinder, halt or even reverse the diffusion of new forms.

Under these conditions, diffusion is a contested process, and the success of the initial movement for alternatives depends on whether or not challengers can muster political support to place and keep alternatives on the agenda (Soule \& King 2005; King, Cornwall, \& Dahlin 2005). Under these conditions, the diffusion of novel practices depends on challengers' abilities to mobilize sufficient power (resources, numbers, organization) to secure authorizing legislation, defend alternatives politically, and so on. For example, the diffusion of mutuals and cooperatives in the US economy was most extensive where anti-corporate forces could secure decisive political victories against corporations, including anti-trust laws and populist railroad regulation (Schneiberg 2002, 2007). Under these conditions, movements matter not just as a conduit, theorizer or assembler of frames and new forms, but also, and more critically, as an accumulator of political power and thus an essential political condition for diffusion.

Considering movements as political conditions for diffusion revises conventional views of the relationship between movements, institutions and outcomes. Arguments about political opportunity structure trace how existing institutional structures condition the effects of movements and mobilization on policies and change. Here, politics and power are institutionally contingent (Amenta et al. 1992; Thornton \& Occasio 1999; Thornton 2002; Bartley \& Schneiberg 2002). As institutional systems become more open to challengers or provide them with elite allies, movements' abilities to translate conventional resources into desired outcomes will increase. Favorable institutional contexts amplify the effect of movement numbers, organizations or resources on change outcomes.

Conceptualizing movements as political forces for diffusion inverts this logic, suggesting that institutional dynamics of diffusion are politically contingent. Whether or not actors can adopt, borrow or translate 
novel forms depends on the capacities of challenger movements to amass political resources, defend novel forms against counter-attacks, and create favorable political contexts for the spread of alternatives (Schneiberg, King \& Smith 2008). Here, institutional effects depend on movement power. Generally speaking, the likelihood of an organization adopting a new practice increases as professional communities endorse the practice and the number of prior adopters increase. Professional endorsement and increased prevalence of practices increases their legitimacy. But, where novel forms are subject to contestation, diffusion will require the mobilization of numbers, resources or organization to defend and protect these alternatives. Absent such mobilization, endorsement or prior adoption will have little or no effect on subsequent adoption. Yet as champions of alternatives mobilize and shift the balance of power, endorsement and prior adoptions will have increasingly powerful effects on subsequent adoption, translation or other institutional processes.

Overall, our knowledge of how movements create favorable political contexts for the diffusion and translation of alternatives is relatively undeveloped. However, future research can draw on both a multi-level perspective and existing strategies for modeling diffusion. In principle, movements can support diffusion as a political force at either the field-level or within organizations. Movements can raise the overall receptivity of organizations to new practices by amassing numbers and resources to contest fieldwide authorities, report success stories in media, enhance the visibility of new practices, or demonstrate the possibility of disruption and change. As movements mobilize effectively at this level, they create political space for alternatives and multiple logics across entire fields, increasing the risk of adoption of novel practices in the aggregate.

Alternatively, movements can shift the balance of power and enhance receptivity by mobilizing 'locally' within individual organizations and making particular organizations or subsets of organizations susceptible to alternatives that are endorsed or adopted by peers. Here, movements operating as political forces within organizations can fuel a differential flow of a novel practices across organizations.

Furthermore, as movements become more powerful, they can fuel variation in the content of practices that diffuse within fields. In the recycling case, activist groups on campuses pushed colleges and universities to go beyond minimal approaches to recycling staffed by part-time custodial staff to adopt programs with full-time ecologically-committed coordinators (Lounsbury 2001). Similarly, in the insurance case, increasing the political strength of anti-corporate forces drove some states beyond limited, anti-discrimination forms of price regulation to full rate control measures that gave regulators authority to order comprehensive changes in rates (Schneiberg \& Bartley 2001).

Fortunately, well-developed tools are available for analyzing movements as political conditions for diffusion, provided measures of movement strength or presence are available. To analyze how movements create possibilities for diffusion by shifting the balance of power at the field-level, models of adoption can employ interaction effects to examine whether the political strength of movements at the field-level moderates the effects on organizational adoption of prior adoption by peers or endorsement by expertprofessionals. To analyze these dynamics at the organizational level, a similar strategy could be used, provided measures are available of the presence, strength or efficacy of movements within organizations. Researchers could again use interaction effects to see if the strength of movements in organizations increases the effects of prevalence or endorsement on the likelihood of those organizations adopting novel practices.

Alternatively, one can use heterogeneous diffusion models (Strang \& Soule 1998) to see whether increasing movement strength within organizations renders them more susceptible to the influence of peers 
or professions. As Soule's (2006) study of university divestment shows, student protests on campuses against investing in South Africa did not directly promote divestment. But by increasing awareness among administrators of university and surrounding communities, demonstrations were a nagging reminder that rendered colleges and universities more vulnerable to legitimacy pressures, making them more likely to divest as their peers jumped on the bandwagon.

Finally, future research can use existing analytical strategies, including competing hazards models, to analyze how growing movement strength might promote the diffusion of increasingly varied, comprehensive or radical alternatives (Lounsbury 2001; Schneiberg \& Bartley 2001). In this way, too, institutionalists can address how movements as political forces shape not just the overall flow of practices across fields, but also the differential flow of alternatives and practice variants within them.

\section{The origins of institutions: history, sequence and layering}

An important and neglected question in neoinstitutionalism is where institutions such as fields, practices or paths come from and how they are forged or elaborated over time. As sociologists have emphasized, there is never a clean slate. Rather, new fields and arenas of social life are typically constructed from the rubble, or flotsam and jetsam, of previous institutions or paths not taken (Stark 1996; Schneiberg 2007) or from variations produced within extant fields (Lounsbury \& Crumley 2007). After all, as Meyer and Rowan (1977: 345) observe in their classic piece, 'the building blocks for organizations come to be littered around the social landscape; it takes only a little entrepreneurial energy to assemble them into a structure.' Moreover, new systems are often not created in one fell swoop, through one wave of diffusion or comprehensives settlements. Rather, paths may emerge through multiple waves, over time, via sequences or successive stages of translation, layering, theorization and assembly that elaborate and innovate on previous, partial accomplishments (Streeck \& Thelen 2005). And central to field and path creation is some sort of collective mobilization or movement, not just a single burst of organization, but also waves or cycles of mobilization and organizational formation.

The parallels between institutionalist imageries of path creation as waves of layering, on the one hand, and movement research on cycles of mobilization and protest, on the other, suggest that linking the two can provide new insights for future research on path creation and change, while adding new historical dimensions to neo-institutional scholarship. Movement scholars have done important work in highlighting the sequencing of social movements and cycles of protest (e.g., Tarrow 1998), tracing, among other things, how contentious politics that involve tactics such as protest are transformed into more conventional forms of political action such as lobbying (Meyer \& Tarrow 1998; Kriesi, Koopmans, Duyvendak, \& Giugni 1995). Minkoff (e.g., 1993, 1997) adds organizational dimensions to the analysis of sequences, showing how the proliferation of radical organizations created legitimacy and favorable political opportunities for subsequent organization by advocacy and practitioner groups, institutionalizing civil rights more deeply within American politics.

For their part, institutionalists have just begun to think in these terms. But preliminary efforts to analyze path and field creation as waves of mobilization, structuration and layering have established a new direction for future research. Lounsbury, Ventresca and Hirsch (2003) took one step in this direction, showing how efforts by early and more radical 'outsider' environmental movements in the 1960s and 1970s to restructure capitalism via not-for-profit, community-based recycling centers unintentionally laid foundations for subsequent mobilization by insider groups in the 1980s to create a for-profit recycling industry. Most non-profit recycling 
centers proved economically non-viable, but they nonetheless trained a generation of Americans in the habits of saving, cleaning, and sorting their trash, a critical cultural infrastructure for the creation of markets based on curb-side pick up.

Schneiberg (2007; Schneiberg, King \& Smith 2008) takes this avenue of research a step further in analyzing the development of mutual, cooperative and publicly owned enterprise in the US economy. For the most part, populists and the radical anti-corporate movements of the late nineteenth and early twentieth centuries faced decisive defeats in their efforts to forge alternatives to corporate capitalism. But even though they collapsed, these movements nevertheless left behind organizational, cultural and institutional legacies - bit and pieces of the paths they had pursued, including theories of order, regulatory fragments, local movement chapters, and alternative systems of enterprise in key industries. These legacies of previous mobilization, in turn, served as legitimating structures, platforms and infrastructures for subsequent collective mobilization in the same or related industries during the Progressive era, and then in the early New Deal. Indeed, successive waves of reformers and anti-corporate forces built or transposed theories, moral sentiments and cooperative forms out from insurance and other early sites of alternative enterprise into the dairy and grain industries, the electrical utility industry and banking, elaborating what amounts to a secondary path of industrial order in the US economy.

Haveman, Rao and Paruchuri's (2007) study of Progressivism and savings and loans associations likewise highlights the distal and often unintended effects of movements on organizational fields. Progressive activists quite deliberately and directly sought to reform a variety of economic institutions, from the railroads to savings and loan associations. Yet they also fostered Progressive models of rationality, bureaucratization and expert management within the thrift industry indirectly, via two intermediary institutions. Activists formed Progressive newspapers that exposed corruption and promulgated reform principles, and promoted city-manager forms of municipal government that exemplified those principles, providing tangible analogies for reformers within the thrift industry. Both institutions promoted the constitutive legitimacy of bureaucracy, prompting saving and loans associations to adopt organizational forms more consistent with 'modernist' moral sentiments.

Nor are these processes confined to economic industries or organizational dynamics. As Armstrong (2002, 2005) illustrates, the legacy of initial movements may also include the establishment of new identities, cultural tools such as frames and logics, and "creative contexts' that enable subsequent groups to continue struggles, mobilize and realize new gains in their efforts. The rise of the New Left in the 1960s enabled the creation of new kinds of lesbian/gay organizational identities in San Francisco in the early 1970s. The development of gay identity politics, in turn, proved crucial in structuring subsequent lesbian/gay organizations as well as enabling changes within mainstream organizations such as the establishment of domestic partner benefits (Creed \& Scully 2000; Scully \& Creed 2005). While this work traces the sequencing and layering from 'outsider' to 'insider' movements, it would be interesting to also understand how 'insider' movements facilitate 'outsider' mobilizations.

Overall, the approach to movements and institutions that we advocate celebrates the heterogeneity of actors, multiple logics and practice variation. A focus on such multiplicity revises the isomorphic imagery of the canonical two-stage diffusion and punctuated equilibrium models (e.g., Tolbert \& Zucker 1983). Such a perspective concentrates less on the contagion of unitary practices or a singular rationality, but rather on multiple forms of rationality that inform the decision making of actors in fields (Bourdieu 1984), and provide foundations for ongoing struggle and contestation. This conceptualization of institutionalization and fields as multiple, fragmented and contested (Schneiberg \& Soule 
2005; Washington \& Ventresca 2004; Lounsbury 2007) is a crucial ontological starting point for a new wave and generation of institutional scholars. And when combined with a renewed attention to movements, it directs analytical attention to how historical legacies of prior social action become embedded in existing fields, providing bases for sequences of mobilization, and the construction of new paths from the elements or ruins of old or forgotten orders. The early work in this direction has proven fruitful and promises to propel institutional analysis for many years to come.

\section{REFERENCES}

Amenta, E., B. Carruthers, \& Y. Zylan et al. 1992. 'A hero for the aged? The Townsend Movement, the Political Mediation Model, and the U.S. old-age policy, 1934-1950.' American Journal of Sociology, 98: 308-39.

Amenta, E. \& Y. Zylan. 1991. 'It happened here: Political opportunity, the new institutionalism and the Townsend Movement.' American Sociological Review, 56: 250-65.

Armstrong, E.A. 2002. Crisis, collective creativity, and the generation of new organizational forms: The transformation of lesbian/gay organizations in San Francisco. Research in the Sociology of Organizations, 19: 369-406.

Armstrong, E.A. 2005. From struggle to settlement: The crystallization of a field of lesbian/gay organizations in San Francisco, 1969-1973. In G.F. Davis, D. McAdam, W.R. Scott \& M.N. Zald (eds.), Social movements and organization Theory (pp. 161-188). Cambridge, U.K.: Cambridge University Press.

Baron, J.P., Dobbin, F. \& Jennings, P.D. 1986. War and peace: The evolution of modern personnel administration in U.S. industry. American Journal of Sociology, 92: 250-283.

Bartley, T. \& M. Schneiberg. 2002. Rationality and institutional contingency: the varying politics of economic regulation in the fire insurance industry. Sociological Perspectives, 45(1): 47-79.
Beckert, J. 1999. Agency, entrepreneurs, and institutional change. The role of strategic choice and institutionalized practices in organizations. Organization Studies, 20 : 777-799.

Bourdieu, P. 1984. Distinction: a social critique of the judgment of taste. Cambridge: Harvard University Press.

Campbell, John. 2004. Institutional change and globalization. Princeton: Princeton University Press.

Campbell, John. 2005. Where do we stand? Common mechanisms in organizations and social movements research. Pp. 41-68 in G.F. Davis, D. McAdam, W.R. Scott \& M.N. Zald (eds.), 2005. Social movements and organization theory. Cambridge, U.K.: Cambridge University Press.

Carroll, G.R. \& Swaminathan, A. 2000. Why the microbrewery movement? Organizational dynamics of resource partitioning in the U.S. brewing industry. American Journal of Sociology, 106: 715-762.

Carruthers, B.G. \& Babb, S. 1996. The color of money and the nature of value: Greenbacks and gold in postbellum America. American Journal of Sociology, 101: 1556-1591.

Clemens, E.S. 1993. Organizational repertoires and institutional change: Womens' groups and the transformation of U.S. politics, 1890-1920. American Journal of Sociology, 98: 755-798.

Clemens, E.S. 1997. The people's lobby: Organizational innovation and the rise of interest group politics in the United States, 1890-1925. Chicago: University of Chicago Press.

Clemens, E.S. and Cook, J. 1999. Politics and institutionalism: Explaining durability and change. Annual Review of Sociology, 25: 441-466.

Colyvas, Jeannette \& Powell, W. 2006. Roads to institutionalization. Research in Organizational Behavior,. 27: 305-53.

Creed, W.E.D. \& Scully, M. 2000. Songs of ourselves: Employees' deployment of social identity in workplace encounters. Journal of Management Inquiry, 9: 391-412.

Creed, W.E.D., Scully, M.A. \& Austin, J.R. 2002. Clothes make the person: The tailoring of legitimating accounts and the social construction of identity. Organization Science, 13: 475-496. 
Davis, Gerald F. \& Doug McAdam. 2000. Corporations, classes, and social movements after managerialism. Research in Organizational Behaviour, 22: 195-238.

Davis, G. F., \& T. Thompson. 1994. A social movement perspective on corporate control. Administrative Science Quarterly, 39: 141-173.

Davis, G.F. \& Zald, M.N. 2005. Social change, social theory, and the convergence of movements and organizations. In G.F. Davis, D. McAdam, W.R. Scott \& M.N. Zald (eds.), Social movements and organization theory (pp. 335-350). Cambridge, U.K.: Cambridge University Press.

DiMaggio, Paul J. 1988. Interest and agency in institutional theory. In Lynne Zucker (ed.), Institutional patterns and organizations. 3-22. Cambridge, MA: Ballinger.

Dobbin, F. \& Dowd, T. 1997. How policy shapes competition: Early Railroad foundings in Massachusetts. Administrative Science Quarterly, 42: 501-529.

Edelman, L.B. 1990. Legal environments and organizational governance: The expansion of due process in the American workplace. American Journal of Sociology, 95: 1401-1440.

Edelman, L. B. 1992. Legal ambiguity and symbolic structures: Organizational mediation of civil rights law. American Journal of Sociology, 97: 1531-1576.

Edelman, L.B. 2006. Constructed legalities: The endogeneity of law. In W. Powell and D. Jones (eds.), How institutions change. Chicago: University of Chicago Press.

Elsbach, K. \& R Sutton. 1992. Acquiring organizational legitimacy through illegitimate actions: A marriage of institutional and impression management theories. Academy of Management Journal, 4: 699-738.

Fiss, P.C. \& Zajac, E.J. 2004. The diffusion of ideas over contested terrain: The (non)adoption of a shareholder value orientation among German firms. Administrative Science Quarterly, 49: 501-534.

Fligstein, Neil 1990. The transformation of corporate control. Cambridge, MA: Harvard University Press.

Fligstein, N. 1996. A political-cultural approach to market institutions. American Sociological Review, 61: 656-673.

Fligstein, N. 2001. The architecture of markets: An economic sociology of twenty first century capitalism. Princeton: Princeton University Press.

Frank, D.B., A. Hironaka and E. Schofer. 2000. Environmentalism as a Global Institution. American Sociological Review, 65: 122-127.

Frickel, Scott and Gross, Neil. 2005. A general theory of scientific/intellectual movements. American Sociological Review, 70: 204-232.

Galaskiewicz, J. \& Wasserman, S. 1989. Mimetic processes within an interorganizational field: An empirical test. Administrative Science Quarterly, 34: 454-479.

Garud, R. \& Karnoe, P. (eds.), 2001. Path dependence and creation. Mahwah, NJ: Lawrence Erlbaum.

Giugni, M., McAdam, D. \& Tilly, C. 1999. How movements matter. Minneapolis, MN: University of Minnesota Press.

Greenwood, R., \& Hinings, C.R. 1996. Understanding radical organizational change: Bringing together the old and the new institutionalism. Academy of Management Review, 21: 1022-1054.

Greenwood, Royston, Roy Suddaby \& C.R. Hinings. 2002. Theorizing change: The role of professional associations in the transformation of institutional fields. Academy of Management Journal, 45: 58-80.

Guillén, Mauro F. 2006. The Taylorized beauty of the mechanical: scientific management and the rise of modernist architecture. Princeton, NJ: Princeton University Press.

Hargrave, T.J. \& Van de Ven, A.H. 2006. A collective action model of institutional innovation. Academy of Management Review, 31: 864-88.

Haveman, H. Hayagreeva Rao \& Srikanth Paruchuri. 2007. The winds of change: The Progressive movement and the bureaucratization of thrift. American Sociological Review, 72: 117-42.

Hironaka, A. \& E. Schofer. 2002. Decoupling in the environmental arena: The case of environmental impact assessments. In A. Hoffman and M. Ventresca (eds.), Organizations, policy and the natural environment. Stanford: Stanford University Press.

Hirsch, P. \& Lounsbury, M. 1997. Ending the family quarrel: Towards a reconciliation of 'old' and 'new' institutionalisms. American Behavioral Scientist, 40: 406-418.

Hoffman, A. 1999. Institutional evolution and change: Environmentalism and the US 
chemical industry. Academy of Management Journal, 42: 351-71.

Hwang, H \& W. Powell, 2005. 'Institutions and Entrepreneurship,' in Sharon Alvarez, Rashesh Agrawal and Olav Sorenson, Handboo of Entrepreneurial Research. New York: Springer: 179-210.

Ingram, P. \& Rao, H. 2004. Store wars. American Journal of Sociology, 110: 446-487.

Jepperson, R. 1991. Institutions, institutional effects, and institutionalism. In W.W. Powell \& P.J. DiMaggio (eds.), The new institutionalism in organizational analysis. Chicago: University of Chicago Press: 143-163.

Keck, M.E. \& Sikkink, K. 1998. Activists beyond borders. Ithaca, NY: Cornell University Press.

King, Brayden G., Cornwall, Marie, \& Dahlin, Eric C. 2005. Winning woman suffrage one step at a time: Social movements and the logic of the legislative process. Social Forces, 83: 1211-1234.

Kriesi, H., Koopmans, R., Duyvendak, J.W. \& Giugni, M.G. 1995. The politics of new social movements in Western Europe: A comparative analysis. Minneapolis, MN: University of Minnesota Press.

Laraña, E., Johnston, H. \& Gusfield, J.R. (eds.), 1994. New social movements: From ideology to identity. Philadelphia: Temple University Press.

Lipsky, M. 1968. Protest as a political resource. American Political Science Review, 62: 1144-1157.

Lawrence, T.B. \& Suddaby, R. 2006. Institutions and Institutional Work. In S. Clegg, C. Hardy, T.B. Lawrence \& W. Nord (eds.) The Sage handbook of organization studies (2nd edn): pp. 215-254. London: Sage.

Lounsbury, M. 2001. Institutional sources of practice variation: Staffing college and university recycling programs. Administrative Science Quarterly, 46: 29-56.

Lounsbury, M. 2005. Institutional variation in the evolution of social movements: Competing logics and the spread of recycling advocacy groups. In G.F. Davis, D. McAdam, W.R. Scott \& M.N. Zald (eds.), Social movements and organization theory (pp. 73-95). Cambridge, U.K.: Cambridge University Press.

Lounsbury, M. 2007. A tale of two cities: Competing logics and practice variation in the professionalizing of mutual funds.
Academy of Management Journal, 50: 289-307.

Lounsbury, M. and Crumley, E.T. 2007. New practice creation: An institutional approach to innovation. Organization Studies, 28: 993-1012.

Lounsbury, M., Ventresca, M.J. \& Hirsch, P.M. 2003. Social movements, field frames and industry emergence: A Cultural-political perspective of U.S. recycling. Socio-Economic Review, 1: 71-104.

Maguire, S., Hardy, C., \& Lawrence, T. B. 2004. Institutional entrepreneurship in emerging fields: HIV/AIDS treatment advocacy in Canada. Academy of Management Journal, 47(5): 657-679.

Marquis, C. \& Lounsbury, M. 2007. Vive la résistance: Consolidation and the institutional contingency of professional countermobilization in US banking. Academy of Management Journal, 50: 799-820.

McAdam, D. 1988. Freedom summer. Oxford: Oxford University Press.

McAdam, D. 1999. Political process and the development of black insurgency, 1930-1970 (rev. edn). Chicago: University of Chicago Press.

McAdam, D., McCarthy, J.D. \& Zald, M.D. 1996. Comparative perspectives on social movements. NY: Cambridge University Press.

McAdam, D. \& Scott, W.R. 2005. Organizations and movements. In G.F. Davis, D. McAdam, W.R. Scott \& M.N. Zald (eds.), Social movements and organization theory (pp. 4-40). Cambridge, U.K.: Cambridge University Press.

McAdam, D., Tarrow, S. \& Tilly, C. 2002. The dynamics of contention. Cambridge, UK: Cambridge University Press.

McCarthy, J.D. \& Zald, M.N. 1977. Resource mobilization and social movements: A partial theory. American Journal of Sociology, 82: 1212-1241.

Meyer, D.S. \& Tarrow, S. (eds.), 1998. The social movement society. Lanham, MD: Rowman \& Littlefield.

Meyer, J. \& Rowan, B. 1977. Institutional organizations: Formal structure as myth and ceremony. American Journal of Sociology, 83(2): 340-363.

Minkoff, D.C. 1993. The organization of survival: Women's and racial-ethnic voluntarist and activist organizations, 1955-1985. Social Forces, 71: 887-908. 
Minkoff, D.C. 1997. The sequencing of social movements. American Sociological Review, 62: 779-799.

Moore, Kelly. 1996. Organizing integrity: American science and the creation of public interest organizations, 1955-1975. American Journal of Sociology, 101: 1592-1627.

Moore, K. \& Hala, N. 2002. Organizing identity: The creation of Science for the People. Research in the Sociology of Organizations, 19: 311-343.

Morrill, Calvin. 2006. Institutional change and interstitial emergence: The growth of alternative dispute resolution in American law, 1965-1995. In W. Powell and D. Jones (eds.), How institutions change. Chicago: University of Chicago Press.

Pierson, Paul. 2000. Increasing returns, path dependence, and the study of politics. American Political Science Review, 94: 251-267.

Raeburn, Nicole. 2004. Inside out: The struggle for lesbian, gay and bisexual rights in the workplace. Minneapolis, MN: University of Minnesota Press.

Rao, Hayagreeva. 1998. Caveat emptor: The construction of nonprofit consumer watchdog organizations. American Journal of Sociology, 103: 912-961.

Rao, Hayagreeva, Monin, P. \& Durand, Rodolphe. 2003. Institutional change in Touque Ville: Nouvelle cuisine as an identity movement in French gastronomy. American Journal of Sociology, 4: 795-843.

Rao, Hayagreeva, Calvin Morrill, \& Mayer N. Zald. 2000. Power plays: Social movements, collective action and new organizational forms. Research in Organizational Behavior, 22: 237-282.

Schneiberg, M. 1999. Political and institutional conditions for governance by association: Private order and price controls in American fire insurance. Politics and Society, 27: 67-103.

Schneiberg, M. 2002. Organizational heterogeneity and the production of new forms: Politics, social movements and mutual companies in American fire insurance, 1900-1930. Research in the Sociology of Organizations, 19: 39-89.

Schneiberg, M. 2005. Combining new institutionalisms: Explaining institutional change in
American property insurance. Sociological Forum, 1: 93-137.

Schneiberg, M. 2007. What's on the path? Path dependence, organizational diversity and the problem of institutional change in the US economy, 1900-1950. SocioEconomic Review, 5: 47-80.

Schneiberg, M. \& Bartley, T. 2001. Regulating American industries: Markets, politics, and the institutional determinants of fire insurance regulation. American Journal of Sociology, 107: 101-146.

Schneiberg, M. \& Soule, S.A. 2005. Institutionalization as a contested, multilevel process: The case of rate regulation in American fire insurance. In G.F. Davis, D. McAdam, W.R. Scott \& M.N. Zald (eds.), Social movements and organization theory (pp. 122-160). Cambridge, U.K.: Cambridge University Press.

Schneiberg, M. \& Clemens, E.S. 2006. The typical tools for the job: Research strategies in institutional analysis. Sociological Theory, 3: 195-227.

Schneiberg, M., King, M., \& Smith, T. 2008. Social movements and organizational form: Cooperative alternatives to corporations in the American insurance, dairy and grain industries. American Sociological Review: Forthcoming.

Schofer, E. \& A. Hironaka. 2005. The effects of world society on environmental protection outcomes. Social Forces, 84: 25-47.

Scott, W.R. 2001. Institutions and organizations (2nd edn). Newbury Park, CA.: Sage.

Scott, W.R., Ruef, M., Mendel, P. \& Caronna, C. 2000. Institutional change and organizations: Transformation of a healthcare field. Chicago: University of Chicago Press.

Scully, M. \& Segal, A. 2002. Passion with an umbrella: Grassroots activists in the workplace. Research in the Sociology of Organizations, 19: 127-170.

Scully, M. \& Creed,W.E.D. 2005. Subverting our Stories of Subversion. In G.F. Davis, D. McAdam, W.R. Scott \& M.N. Zald (eds.), Social movements and organization theory (pp. 310-332). Cambridge, U.K.: Cambridge University Press.

Seo, M. \& Creed, W.E.D. 2002. Institutional contradictions, praxis, and institutional change: A dialectical perspective. Academy of Management Review, 27: 222-247. 
Soule, S. 2004. 'Going to the chapel? Same-sex marriage bans in the United States, 1973-2000.' Social Problems, 4: 453-77.

Soule, S. 2006. Divestment by colleges and universities in the United States: Institutional pressures toward isomorphism. In W. Powell and D. Jones (eds.), How institutions change. Chicago: University of Chicago Press.

Soule, S. \& S. Olzak. 2004. When do movements matter? The politics of contingency and the Equal Rights Amendment. American Sociological Review, 69: 473-97.

Soule, S. and B. King. 2006. The stage of the policy process and the Equal Rights Amendment, 1972-1982. American Journal of Sociology, 6: 1871-1909.

Strang, D. \& Chang, M.Y. 1993. The International Labor Organization and the welfare state: Institutional effects on national welfare spending, 1960-1980. International Organization, 47: 235-262.

Strang, David \& John W. Meyer. 1993. Institutional conditions for diffusion. Theory and Society, 22: 487-512.

Strang, D. \& Jung, D. 2005. Organizational change as an orchestrated social movement: Recruitment to a corporate quality initiative. In G.F. Davis, D. McAdam, W.R. Scott \& M.N. Zald (eds.), Social movements and organization theory (pp. 280-309). Cambridge, U.K.: Cambridge University Press.

Strang, D. \& Soule, S.A. 1998. Diffusion in organizations and social movements: From hybrid corn to poison pills. Annual Review of Sociology, 24: 265-290.

Stark, D. 1996. Recombinant property in East European capitalism. American Journal of Sociology, 101(4): 993-1027.

Streeck, Wolfgang \& Thelen, Kathleen. 2005. Beyond continuity: Institutional change in advanced political economies. Oxford: Oxford University Press.

Stryker, R. 1994. Rules, resources, and legitimacy processes: Some implications for social conflict, order, and change. American Journal of Sociology, 99: 847-910.

Stryker, R. 2000. Legitimacy processes as institutional politics: Implications for theory and research in the sociology of organizations. Research in the Sociology of Organizations, 17: 179-223.
Sutton J.R., Dobbin, F., Meyer, J., Scott, W.R. 1994. The legalization of the workplace. American Journal of Sociology, 99: 944-971.

Sutton, John R. \& Dobbin, Frank. 1996. Responses to legal uncertainty in U.S. firms, 1955 to 1985. American Sociological Review, 61: 794-811.

Tarrow, S. 1998. Power in movement: Social movements and contentious politics (2nd edn). New York: Cambridge University Press.

Thelen. K. 2004. How institutions evolve: The political economy of skills in Germany, Britain, the United States and Japan. New York, Cambridge University Press.

Thornton, P.H. 2002. The rise of the corporation in a craft industry: Conflict and conformity in institutional logics. Academy of Management Journal, 45: 81-101.

Thornton, P.H. \& Ocasio, W. 1999. Institutional logics and the historical contingency of power in organizations: Executive succession in the higher education publishing industry, 1958-1990. American Journal of Sociology, 105: 801-843.

Tolbert, P.S., \& L.G. Zucker. 1983. Institutional sources of change in the formal structure of organizations: The diffusion of civil service reform, 1880-1935. Administrative Science Quarterly, 28: 22-39.

Vogus, T.J. \& Davis, G.F. 2005. Elite mobilizations for antitakeover legislation, 1982-1990. In G.F. Davis, D. McAdam, W.R. Scott \& M.N. Zald (eds.), Social movements and organization theory (pp. 96-121). Cambridge, U.K.: Cambridge University Press.

Wade, James B., Swaminathan, A. \& Saxon, M.S. 1998. Normative and resource flow consequences of local regulations in the American brewing industry, 1845-1918. Administrative Science Quarterly, 43: 905-935.

Washington, M., \& Ventresca. M.J. 2004. How organizations change: The role of institutional support mechanisms in the incorporation of higher education visibility strategies, 1874-1995. Organization Science, 15: 82-96.

Zald, M.N. \& Berger, M.A. 1978. Social movements in organizations: Coup d'etat, insurgency, and mass movements. American Journal of Sociology, 83: 823-861. 